\title{
VERKENNING VAN TEOLOGIESE TYDSKRIFTE
}

DIE redaksie beoog om in hierdie rubriek die aandag van die leser te vestig op belangrike en interessante artikels wat in ander teologiese tydskrifte verskyn het. 'n Mens, ook 'n predikant kan nie alles lees nie en daarom is ondergetekende redaksielid gevra om die aandag te vestig op belangrike publikasies wat breër aandag verdien. So 'n rubriek kan goedskiks deur enige leser aangevul word, wanneer hy op artikels aandag wil vestig.

In Geref. Theol. Tijdschrift wat onder redaksie staan van hooglerare van die V.U. en Kampen, Nederland, vind ons in die uitgawe van Des. 1975 twee besonder belangrike artikels. Die eerste een is van C. Korenhof: lets over de marxistische visie op de Reformatie. Korenhof wys vir ons hoe met name in die DDR 'n herskrywing van die Kerkgeskiedenis plaasvind en die Lutherse Reformasie deur die bril van Marx en die Marxisme gelees word. Uit hierdie artikel kan ons ook leer hoe die siening op Thomas Müntzer soos Ernst Bloch hom geskilder het, nie vry is van marxistiese beinvloeding nie. Die tweede artikel is van dr. J. Veenhof: De theologie van J. G. Woelderink. Daar is in Nederland iets soos 'n eerherstel van Woelderink aan die gang. Sy artikel kan ons prikkel om ook hier in Suid-Afrika aan die werke van Woelderink weer meer aandag te gee. Wel moet ons onderskeid maak tussen die jong-Woeldrink en die ou-Woelderink, maar wat hierdie teoloog geskrywe het oor die verbond, oor geloofsbevinding en oor die betroubaarheid van Gods beloftes is seker die moeite werd om aandag aan te gee.

Kerk en Theologie is 'n teologiese tydskrif uit die middegroep in die Herv. Kerk in Nederland. Dis altyd die moeite werd om telkens weer die Kroniek te lees wat o.a. versorg word deur drs. A. A. Spijkerboer. Hy registreer baie noukeurig alles wat daar op die terrein van kerk en theologie in Europa gebeur en voorsien dit in boeiende styl van ewewigtige kommentaar. Ons verwys hier na die nommer van Okt. 1975 oor die sg. Barth-Stiftung en die bekende Barth-biografie van Eberhard Busch. In daardie selfde uitgawe vind ons ook twee uiters boeiende artikels van dr. G. de $R u$ en prof. A. Geense oor die Christologie van H. Berkhof. Berkhof se dogmatiek (Christelijk Geloof, 1974) het geskok en veral sy Christologie het baie vrae opgeroep. In dieselfde nommer vind ons ook 'n antwoord van Berkhof.

Wie die boeiende diskussie rondom die boek van Berkhof wil volg, moet tog veral kennis neem van 'n referaat van prof. C. Graafland in die Teol. Tydskrif Theologia Reformata, 'n blad wat redigeer word deur manne van die Geref. Bond binne die Herv. Kerk in Nederland en professore van die Chr. Geref. Kerken te Apeldoorn. In die nommer van Maart 1976 skryf Graafland oor: Enkele aspecten van de christelijke geloofsleer bij $d r$. H. Berkhof. Hy toon baie duidelik aan hoe Berkhof invloed van die evolusionistiese denke ondergaan het wat noodwendig moet uitloop op 'n verswakking van die sondebesef. Wat 'n mens veral tref is die bewoë appèl van Graafland op Berkhof (wat ook self teenwoordig was 
toe die referaat gelewer is) om tog nie met hierdie „uitermate gevaarlijke spel" voort te gaan nie.

In Vox Reformata 'n uitgawe van die Teol. Fakulteit van die Geref. kerke in Australië en Nieu-Seeland, verskyn in die nommer van Nov. 1975 'n inougurele rede Preparing to preach from the Old Testament, van prof. A. M. Harman. In sy rede dui hy die belang. rikheid van die vak openbaringsgeskiedenis aan. Hy noem dit „biblical theology" soos G. Vos dit verstaan het. Met hierdie heldere uiteensetting kan elkeen wat uit die O.T. wil preek sy wins maak.

Hervormde Teologiese Studies wil die Bybels-Reformatoriese teologie in Suid-Afrika bevorder en gaan uit van die Fakulteit Teologie A van die Nederd. Herv. Kerk te Pretoria.

In Jaargang 29, afl. 1 en 2 verskyn 'n mooi bydrae van $\mathrm{dr}$. J. H. Koekemoer: Enkele opmerkings oor die nuwe teologie en meer bepaald sy Christologie. Hierdie bydrae kan ons ook help om die agtergronde van Berkhof se Christologie beter te verstaan. In dieselfde nommer: Die godsdienstig-kulturele bydrae van die Hugenote tot die Afrikaanse volkswording.

Ned. Geref. Teol. Tydskrif word veral gevul met bydraes van teol. professore van die N.G. Teologiese Skole van Pretoria en Stellenbosch. In die nommer van Januarie 1976 vind ons ' $n$ indringende artikel van prof. D. W. de Villiers: Waarheen wil ons met die opleiding van predikante? Insiggewend is sy verslag van ontmoetings met teoloë uit Oos-Duitsland op 'n kongres te Rüschlikon. Dieselfde nommer bevat ook 'n pragtige eksegetiese studie van prof. Jannie du Preez oor: "Sperma autou" in 1 Joh. $3: 9,35$. In die Maartnommer poog prof. F. C. Fensham om 'n oplossing te vind vir die ou probleem van Wet en Evangelie. Hy doen dit - en dit maak sy artikel ongelooflik boeiend - vanuit die vraag of daar ook wetmatig. heid is in sekere Ou-Testamentiese regstipulasies. Daar kan ook gerus aandag gegee word aan die bydrae in dieselfde nommer van prof. I. J. du Plessis: Op soek na 'n geldige metode van Skrifondersoek. Du Plessis vergelyk tekskritiek, literêre kritiek, vormkritiek, redaksiekritiek en die sg. linguisitiese metode en gee in enkele gevolgtrekking baie ewewigtige konklusies wat werklik die moeite werd is om te oorweeg. In dieselfde nommer kan ons by wyse van aangename afwisseling 'n brokkie romantiek uit die Reformasietyd lees. Dr. M. C. Kitshof skrywe oor Calvyn se amoreuse strategie onder die titel: Die huwelik van 'n Hervormer.

Die Fakulteit Teologie van die Universiteit van die Noorde het nou ook sy eie teologiese tydskrif Theologia Viatorum. In die Des. 1975-nummer vind ons $0 . \mathrm{m}$. 'n baie insiggewende bydrae van prof. P. Bolink: Towards Church Union in Independent Zambia.

In Unisa se teologiese tydskrif Theologia Evangelica, Jrg. VIII, nr. 3 van Sept. 1975 verskyn 'n skitterende artikel van prof. C. F. D. Moxule: The pre-existence of Christ in the light of the experience of New Testament Christians. In die lig van die diskussie rondom Berkhof se Christologie is hierdie artikel baie insiggewend.

Ten slotte wil ons nog aandag vra vir die tydskrif van die S.A. Werkgemeenskap vir sendingwetenskap: Missionalia onder die bekwame redaksie van prof. David Bosch. Alleen al vanweë sy Missio- 


\section{In die Skriflig}

logical Abstracts is hierdie blad baie waardevol. In Volume 3 verskyn 'n mooi bydrae van dr. M. A. Kruger: Renewal in Catechesis, waarin hy in verband met die catechese op die sendingveld by die jong kerke baie behartigenswaardige opmerkings mak.

L. Floor.

\section{BOEKE ONTVANG VIR RESENSIE}

K. Nürnberger: Sistematiese Teologie. Genadendal, Morawiese Boekedepot, 1975, 608 bl. Teol. Boekereeks nr. 20. R4,90.

NGKSA. Breë Moderatuur: Ras, Volk en Nasie en Volkereverhoudinge in die lig van die Skrif. N.G. Kerk-uitgewers, 1975. 102 bl. 